\section{Concentration Response of Zonal Geranium and Potted Chrysanthemum to Uniconazole}

\author{
Harry K. Tayama ${ }^{1}$ and Stephen A. Carver ${ }^{2}$ \\ Department of Horticulture, The Ohio State University, Columbus, \\ OH 43210
}

Additional index words. Dendranthema $\times$ grandiflorum, Pelargonium hortorum, chlormequat, daminozide, Sumagic, XE-1019

\begin{abstract}
Uniconazole spray or drench applications to 'Yours Truly' zonal geranium (Pelargonium $\times$ hortorum L.H. Bailey) and 'Bright Golden Anne' and Yellow Favor' chrysanthemums [Dendranthema xgrandiflorum (Ramat.) Kitamura] were made to evaluate efficacy and identify optimum application concentrations. Spray applications at $10 \mathrm{mg}$ a.i./liter retarded stem elongation in unpinched zonal geranium comparable to chlormequat at $1500 \mathrm{mg}$ a.i./liter. 'Bright Golden Anne' was more sensitive to uniconazole than 'Yellow Favor'. Uniconazole spray concentrations of 20 to $30 \mathrm{mg}$ a.i./ liter retarded plant height equal to daminozide at $5000 \mathrm{mg}$ a.i./liter. Chemical names used: 2-chloro-N,N,N-trimethylethanaminium chloride (chlormequat); butanedioic acid mono (2,2-dimethylhydrazide) (daminozide); (E)-(S)-1-(4-chlorophenyl)-4,4-dimethyl2-(1,2,4-triazol-1-yl)-pent-1-ene-3-ol (uniconazole).
\end{abstract}

Uniconazole is a member of the triazoles, a potent new class of chemical growth regulators. Triazoles, which include $\alpha-(1-$ methylethyl) $-\alpha-[4-($ trifluoromethoxy)phenyl]-5-pyrimidinemethanol (flurprimidol) and $\beta-[(4-$ chlorophenyl)methyl] $-\alpha-(1,1$-dimethylethyl)-1H-1,2,4-triazole-1-ethanol (paclobutrazol), have demonstrated effective height control on a wide range of plant material, including woody ornamentals, turfgrass, fruit crops, bedding plants, and potted floricultural crops (Davis et al., 1988). Specifically, effective height control with uniconazole has been demonstrated on potted chrysanthemum (Starman 1990; Wilfret, 1988), petunia (Petunia hybrida Vilm. 'Summer Madness'), coleus (Coleus blumei Benth. 'Red Wizard'), celosia (Celosia argentea L. 'Geisha'), impatiens (Impatiens holstii Engl. and Warb. 'Blush'), snapdragon (Antirrhinum majus L. 'Floral Carpet'), salvia (Salvia splendens Sello ex Nees 'Red Hot

Received for publication 2 Oct. 1990. Manuscript no. 265-90. Salaries and research support provided by state and federal funds appropriated to The Ohio State Univ., Ohio Agricultural Research and Development Center. We gratefully acknowledge Ulery Greenhouse Co., Springfield, Ohio, and West Hills Greenhouse, Cincinnati, for donation of zonal geraniums; Yoder Brothers, Barberton, Ohio, for donation of chrysanthemum cuttings; Grace Sierra and Co., Fogelsville, Pa., for donation of Metro-Mix 350; and Smithers-Oasis, Kent, Ohio, for donation of Oasis Strips. Trade names are used in this publication to provide specific information. Mention of a trade name does not constitute a guarantee of the product or an endorsement by The Ohio State Univ. over other products not mentioned. The cost of publishing this paper was defrayed in part by the payment of page charges. Under postal regulations, this paper therefore must be hereby marked advertisement solely to indicate this fact.

${ }^{1}$ Professor.

${ }^{2}$ Research Associate.
Sally') (Barrett and Nell, 1986), vinca [Catharanthus roseus (L.) G. Don 'Little Bright Eye' and 'Little Blanche'] (Barrett and Nell, 1987), carnation (Dianthus carophyllus L. 'Colorado Majestic Mountain') (Pobudkiew- icz and Goldsberry, 1989), Easter lily (Lilium longiflorum Thunb. 'Nellie White') (Miller and Bailey, 1989), 'Yours Truly' zonal geranium (Tayama and Carver, 1990), and poinsettia [Euphorbia pulcherrima (Willd. ex. Klotzsch)] (Stephenson and Shumack, 1987).

The initial use label for uniconazole does not include zonal geranium, but does include potted chrysanthemum at spray concentrations of 10 to $30 \mathrm{mg}$ a.i./liter. There is little published research evaluating optimal uniconazole concentrations for these crops. This experiment was designed to evaluate the relative efficacy of a range of uniconazole spray and drench application concentrations against the industry standards of daminozide on chrysanthemum and chlormequat on zonal geranium.

Zonal geranium. The first trial was initiated on 5 Jan. 1989, when 150 'Yours Truly' zonal geraniums growing in a $90 \%$ sphagnum peat : $10 \%$ Styrofoam (v/v) medium in OS-liter plastic containers were received and spaced at $23-\mathrm{cm}$ centers in an unshaded glasshouse. Plants were pinched to three nodes on 19 Jan. The trial was repeated beginning 5 Apr., when 'Yours Truly' cuttings were stuck into Oasis Strips (Smithers-Oasis, Kent, Ohio), placed under intermittent mist for 4 weeks, and maintained under 27/21C (day/ night). The rooted cuttings were removed from

Table 1. Comparison of the effects of uniconazole spray and drench applications and chlormequat on growth and flowering of 'Yours Truly' geranium.

\begin{tabular}{|c|c|c|c|c|c|c|c|c|}
\hline \multirow{3}{*}{$\begin{array}{l}\text { Growth regulator } \\
\text { applied }^{z}\end{array}$} & \multicolumn{2}{|c|}{$\begin{array}{l}\text { Plant ht } \\
\text { (cm) }\end{array}$} & \multicolumn{2}{|c|}{$\begin{array}{l}\text { Plant diam } \\
(\mathrm{cm})\end{array}$} & \multicolumn{2}{|c|}{$\begin{array}{l}\text { Inflorescences/ } \\
\text { plant }\end{array}$} & \multicolumn{2}{|c|}{$\begin{array}{l}\text { Days to } \\
\text { flower }\end{array}$} \\
\hline & \multicolumn{8}{|c|}{ Expt. ${ }^{y}$} \\
\hline & 1 & 2 & 1 & 2 & 1 & 2 & 1 & 2 \\
\hline Control & 15.3 & 22.4 & 23.3 & 28.0 & 4.3 & 7.2 & 17.3 & 24.3 \\
\hline \multicolumn{9}{|l|}{$\begin{array}{l}\text { Two uniconazole } \\
\text { sprays }\left(\mathrm{mg} \cdot \mathrm{liter}^{-1}\right)\end{array}$} \\
\hline 10 & 14.7 & 14.6 & 22.0 & 21.9 & 4.3 & 6.9 & 20.3 & 26.0 \\
\hline 15 & 15.0 & 11.9 & 21.0 & 16.2 & 4.3 & 6.0 & 19.3 & 24.7 \\
\hline 20 & 14.7 & 11.9 & 21.0 & 17.1 & 4.7 & 6.4 & 16.7 & 25.3 \\
\hline \multicolumn{9}{|l|}{$\begin{array}{l}\text { One uniconazole } \\
\text { drench ( } \mathrm{mg} / \mathrm{pot})\end{array}$} \\
\hline 0.6 & 9.3 & 10.2 & 13.7 & 15.0 & 4.3 & 5.4 & 18.3 & 24.0 \\
\hline 0.9 & 9.0 & 9.8 & 12.7 & 13.7 & 3.7 & 5.3 & 17.3 & 23.3 \\
\hline 1.2 & 9.3 & 10.3 & 12.7 & 12.5 & 4.0 & 5.7 & 19.5 & 24.0 \\
\hline \multicolumn{9}{|l|}{$\begin{array}{l}\text { Two uniconazole } \\
\text { drenches (mg/pot each) }\end{array}$} \\
\hline 0.6 & 9.7 & 10.4 & 13.0 & 13.0 & 3.3 & 5.8 & 21.0 & 24.3 \\
\hline 0.9 & 9.3 & 9.7 & 12.7 & 13.0 & 3.7 & 5.4 & 17.7 & 24.0 \\
\hline 1.2 & 10.0 & 10.3 & 12.0 & 13.6 & 4.0 & 5.1 & 19.3 & 25.0 \\
\hline Two chlormequat sprays, & & & & & & & & \\
\hline $1500 \mathrm{mg} \cdot$ liter $^{-1}$ & 14.2 & 17.1 & 22.1 & 25.7 & 4.7 & 7.5 & 18.9 & 26.0 \\
\hline \multicolumn{9}{|l|}{$\begin{array}{l}\text { Planned comparisons } \\
\text { Two uniconazole sprays }\end{array}$} \\
\hline Two uniconazole sprays & & & & & & & & \\
\hline vs. chlormequat & ** & ** & ** & ** & NS & ** & NS & NS \\
\hline $\begin{array}{l}\text { Spray concn effect } \\
\text { One uniconazole drench }\end{array}$ & NS & $\mathrm{L}^{*}$ & NS & $\mathrm{LQ}^{* *}$ & NS & NS & $\mathrm{L}^{*}$ & NS \\
\hline vs. chlormequat & $* *$ & $* *$ & ** & $* *$ & NS & $* *$ & $*$ & NS \\
\hline $\begin{array}{l}\text { One-drench rate effect } \\
\text { Two uniconazole drenches }\end{array}$ & NS & NS & NS & $\mathrm{L}^{* *}$ & NS & NS & NS & NS \\
\hline vs. chlormequat & $* *$ & $* *$ & $* *$ & $* *$ & NS & $* *$ & NS & NS \\
\hline Two-drench rate effect & NS & NS & NS & NS & NS & NS & NS & NS \\
\hline Control vs. other treatments & $* *$ & $* *$ & ** & ** & NS & $*$ & NS & NS \\
\hline
\end{tabular}

${ }^{2}$ Chlormequat treatment means are the average of nine replicates, while the remaining treatment means are of three replicates.

${ }^{y}$ Experiment 1 was conducted on pinched plants, Expt. 2 on unpinched plants.

$*, * *{ }^{\text {Ns }}$ Significant at $\mathrm{P}=0.05$ or 0.01 or nonsignificant, respectively; linear $(\mathrm{L})$ and quadratic $(\mathrm{Q})$. 
Table 2. Comparison of the effects of uniconazole sprays and drenches and daminozide on growth and flowering of 'Bright Golden Anne' and 'Yellow Favor' chrysanthemum.

\begin{tabular}{|c|c|c|c|c|c|c|c|c|}
\hline \multirow{2}{*}{$\begin{array}{l}\text { Growth regulator } \\
\text { applied }^{z}\end{array}$} & \multicolumn{2}{|c|}{$\begin{array}{l}\text { Plant ht } \\
\text { (cm) }\end{array}$} & \multicolumn{2}{|c|}{$\begin{array}{c}\text { Plant diam } \\
(\mathrm{cm})\end{array}$} & \multicolumn{2}{|c|}{$\begin{array}{c}\text { Inflorescences/ } \\
\text { plant }\end{array}$} & \multicolumn{2}{|c|}{$\begin{array}{c}\text { Days to } \\
\text { flower }\end{array}$} \\
\hline & $\mathrm{BGA}$ & $\mathrm{YF}$ & BGA & YF & BGA & YF & BGA & YF \\
\hline Control & 43.0 & 33.7 & 66.7 & 63.3 & 21 & 18 & 65 & 73 \\
\hline \multicolumn{9}{|l|}{$\begin{array}{l}\text { Three uniconazole } \\
\text { sprays }\left(\mathrm{mg} \cdot \text { liter }^{-1}\right)\end{array}$} \\
\hline 10 & 37.0 & 30.7 & 57.3 & 60.0 & 20 & 17 & 67 & 77 \\
\hline 20 & 31.3 & 30.3 & 55.7 & 59.7 & 22 & 17 & 67 & 75 \\
\hline 30 & $\ldots$ & 27.3 & $\ldots$ & 55.7 & $\ldots$ & 18 & --- & 77 \\
\hline \multicolumn{9}{|l|}{$\begin{array}{l}\text { One uniconazole } \\
\text { drench (mg/pot) }\end{array}$} \\
\hline 1.2 & 27.0 & 31.3 & 49.0 & 61.0 & 19 & 18 & 67 & 76 \\
\hline 2.4 & 25.7 & 29.0 & 49.7 & 60.7 & 19 & 16 & 67 & 75 \\
\hline 3.6 & 23.7 & 28.0 & 46.3 & 56.0 & 18 & 18 & 68 & 77 \\
\hline \multicolumn{9}{|l|}{$\begin{array}{l}\text { Two uniconazole } \\
\text { drenches (mg/pot each) }\end{array}$} \\
\hline 1.2 & 24.3 & 30.7 & 47.3 & 58.3 & 20 & 18 & 67 & 75 \\
\hline 2.4 & 25.0 & 28.7 & 47.7 & 57.7 & 20 & 18 & 67 & 76 \\
\hline 3.6 & 22.3 & 28.0 & 44.7 & 54.7 & 19 & 17 & 69 & 77 \\
\hline \multicolumn{9}{|l|}{ Three daminozide sprays, } \\
\hline $5000 \mathrm{mg} \cdot$ liter $^{-1}$ & 31.9 & 27.6 & 56.6 & 56.6 & 19 & 17 & 67 & 76 \\
\hline \multicolumn{9}{|l|}{ Planned comparisons } \\
\hline $\begin{array}{l}\text { Three uniconazole sprays } \\
\text { vs. daminozide }\end{array}$ & ** & NS & ** & NS & NS & $m *$ & NS & NS \\
\hline $\begin{array}{l}\text { Spray concn effect } \\
\text { One uniconazole drench }\end{array}$ & $\mathrm{L}^{* *}$ & $\mathrm{~L}^{* *}$ & NS & $L^{*}$ & NS & NS & NS & NS \\
\hline vs. daminozide & $* *$ & $*$ & $* *$ & $*$ & NS & $* *$ & NS & NS \\
\hline One-drench rate effect & $\mathrm{L}^{* *} \mathrm{Q}^{*}$ & $L^{* *}$ & $\mathrm{~L}^{*}$ & $\mathrm{~L}^{*}$ & NS & NS & NS & NS \\
\hline Two uniconazole drenches & & & & & & & & \\
\hline vs. daminozide & $* *$ & $*$ & $* *$ & NS & NS & $* *$ & NS & NS \\
\hline Two-drench rate effect & $L^{*} Q^{* *}$ & $\mathrm{~L}^{*}$ & $Q^{*}$ & $\mathrm{~L}^{*}$ & NS & NS & $\mathrm{Q}^{* *}$ & NS \\
\hline Control vs. other treatments & $* *$ & *** & $* *$ & ** & $*$ & 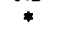 & $* *$ & $* *$ \\
\hline
\end{tabular}

${ }^{2}$ Daminozide treatment means are the average of nine replicates, while the remaining treatment means are of three replicates.

$*,{ }^{* *},{ }^{\mathrm{Ns}}$ Signifieant at $P=0.05$ or 0.01 or nonsignificant, respectively; linear $(\mathrm{L})$ and quadratic $(\mathrm{Q})$.

the mist, planted in OS-liter plastic containers filled with Metro-Mix 350 (Grace Sierra and Co., Fogelsville, Pa.), and topdressed with $2.4 \mathrm{~g}$ of Osmocote $19 \mathrm{~N}-2.6 \mathrm{P}$ 9.9K (Grace Sierra and Co.) on 2 May. Plants in both trials were irrigated manually, as required, with a solution containing $200 \mathrm{mg}$ N/liter from Peter's 20N-4.4P-16.6K (Grace Sierra and Co.). The geraniums were maintained at 15.5 to $21 / 15.5 \mathrm{C}$ (day/night). Inflorescences were regularly removed until the date of the last growth regulator treatments. Senescing leaves were continuously removed until the conclusion of the trials. The first treatment was applied when $5 \mathrm{~cm}$ of new stem growth had developed after pruning in the first trial, 14 Feb., or after planting in the second trial, 26 May. Second treatments were administered 15 days after the first in both trials. The studies were concluded and data collected (except days to flower) 5 weeks following the second applications, i.e., 5 Apr. and 15 July, respectively.

In both trials, 13 treatments were established in a randomized complete block design with three replicates (samples/statistical observations) per treatment and six plants (subsamples) per replication. The treatments were: 1) two spray applications of uniconazole (Un2Sp) at $10 \mathrm{mg}$ a.i./liter; 2) Un2Sp at $15 \mathrm{mg} / \mathrm{liter}^{-1}$; 3) Un2Sp at $20 \mathrm{mg} \cdot$ liter $^{-1}$; 4) one drench application of uniconazole (Un1Dr) at $0.6 \mathrm{mg}$ a.i./pot; 5) Un1Dr at 0.9 $\mathrm{mg} / \mathrm{pot}$; 6) Un1Dr at $1.2 \mathrm{mg} / \mathrm{pot}$; 7) two ble 1). The one exception were pinched geraniums in the first study that received uniconazole sprays. These plants were significantly taller, but still smaller in diameter, than chlormequat-treated plants. However, neither the uniconazole nor chlormequat spray treatments in that first study arrested stem elongation (plant height and diameter) to a commercially acceptable level compared to the nontreated control plants. Uniconazole and chlormequat spray treatments applied to unpinched geraniums used in the second study, however, were very effective. In the second study, stem elongation of unpinched geraniums that received $10 \mathrm{mg}$ uniconazole/ liter was $\approx 65 \%$ that of nontreated control plants, while stem elongation of plants sprayed with uniconazole at 15 or $20 \mathrm{mg} \cdot$ liter $^{-1}$ was $\approx 55 \%$ that of nontreated control plants. The dwarfing induced by all the drench treatments in both studies was extreme. Leaves, petioles, internodes, peduncles, and flowers were all dwarfed (observations only, data not recorded).

Uniconazole reduced the number of inflorescences- in the unpinched geraniums compared to chlormequat, but not in pinched ones. Uniconazole had little effect on number of days to flower compared to chlormequat, with the exception that single uniconazole drenches slightly delayed flowering in pinched geraniums.

It is difficult from these data to identify optimum uniconazole application concentrations. All drench treatments, both single and double applications, produced excessive dwarfing. Uniconazole sprays yielded variable results. An application of $10 \mathrm{mg} \cdot$ liter $^{-1}$ to unpinched 'Yours Truly' zonal geraniums provided a commercially acceptable level of stem elongation with little adverse effect on inflorescence count or days to flower. This same spray concentration, as well as other uniconazole and chlormequat spray concentrations, had little effect on stem elongation of pinched 'Yours Truly'. Tayama and Carver (1990), working with the same cultivar under the same environmental conditions, found that $10 \mathrm{mg} \cdot$ liter $^{-1}$ sprays provided an acceptable level of control of pinched plants.

Potted chrysanthemum. The chrysanthemum study was initiated 11 Jan. 1989 using 'Bright Golden Anne' ('BGA') and reinitiated on 9 May 1989 with 'Yellow Favor' ('YF'). Standard cultural practices (Tayama and Roll, 1989) were followed in both studies. Five rooted cuttings were planted in 1.5liter plastic pots filled with Metro-Mix 350 and topdressed with $4.8 \mathrm{~g}$ of Osmocote (19N2.6P-9.9K). Plants were placed under intermittent mist for 3 days and maintained under long-day conditions (incandescent lights from 2200 to $0200 \mathrm{HR}$ ) and a 21/26.5(7 night/day temperature regime. Plants were then moved to an unshaded glasshouse in the first trial and to a shaded (white-washed, $\approx 50 \%$ shade) glasshouse in the second, with $16.5 / 24$ to $26.5 \mathrm{C}$ night/day cycles and long days. Fertilization was the same as for the zonal geraniums. Plants were pinched to seven leaves when roots had developed to the sides and bottoms of the pots, 28 Jan. in the first trial 
and 23 May in the second. Plants were exposed to short days (black shadecloth from 1700 to $0800 \mathrm{HR}$ ) following pruning. Plant growth regulators were applied at 2-week intervals after the initial treatments, 13 Feb. for 'BGA' and 5 June for 'YF'. 'BGA' was disbudded on 14 Mar. and 'YF' on 3 July. Studies were concluded and data collected (except days to flower) on 4 May and 26 July 1989 when all plants had flowered for the first and second experiments, respectively.

Twelve treatments were established with 'BGA' and 13 with 'YF'. The treatments were: 1) three spray applications of uniconazole (Un3Sp) at $10 \mathrm{mg}$ a.i./liter; 2) Un3Sp at $20 \mathrm{mg} \cdot \mathrm{liter}^{-1}$; 3) Un3Sp at $30 \mathrm{mg} \cdot \mathrm{liter}^{-1}$ (this treatment was dropped from the 'BGA' trial because the second application was missed); 4) one drench application of uniconazole (Un1Dr) at $1.2 \mathrm{mg}$ a.i./pot; 5) Un1Dr at $2.4 \mathrm{mg} /$ pot; 6) Un1Dr at $3.6 \mathrm{mg} /$ pot; 7) two drench applications of uniconazole (Un2Dr), each at $1.2 \mathrm{mg}$ a.i./pot; 8) Un2Dr at $2.4 \mathrm{mg} /$ pot each; 9) Un2Dr at 3.6 $\mathrm{mg} /$ pot each; 10-12) three spray applications of daminozide at $5000 \mathrm{mg}$ a.i./liter; and 13) a water control. The design was the same as for the zonal geranium studies, except each replication contained three pots (subsamples). Sprays were applied at $204 \mathrm{ml}$ of plant growth regulator solution $/ 1 \mathrm{~m}^{2}$ of bench space. About $7 \mathrm{ml}$ was applied per plant at the first application, based on an average plant canopy diameter of $20 \mathrm{~cm}$. Drenches were applied as $120 \mathrm{ml}$ of solution/l.5-liter pot. All spray treatments were applied three times, while the drench treatments were applied once or twice, as described previously.

Plant growth measurements recorded were the same as those measured for the zonal geraniums. Days to flowering were determined for ' $\mathrm{BGA}$ ' from the date of planting to the date that the first plant within each treatment replication exhibited a flower that was two-thirds open (eight to 10 rows of rays extended). For 'YF', days to flower was determined when one-half of the flowers within each treatment replication was two-thirds open. Statistical analyses used were the same as for geraniums.

Height and diameter of 'BGA' and 'YF' chrysanthemums sprayed with 20 or $30 \mathrm{mg}$ uniconazole/liter, respectively, were similar to chrysanthemums sprayed with daminozide. 'BGA' plants treated with uniconazole drenches were significantly smaller (height and diameter) than those treated with daminozide. For 'YF', plants treated with a single uniconazole drench were significantly taller and as wide or wider than those treated with daminozide. The implication is that 'BGA' may be more sensitive to uniconazole, relative to daminozide, than is 'YF' (Table 2).

Plant growth regulator treatments, on average, slightly reduced the number of inflorescences in 'BGA', but the reduction $(\approx 1.3$ inflorescences/plant) likely would not be commercially important. Similarly, all chemical treatments slightly delayed flowering in both cultivars. However, the number of inflorescences per plant or the days to flower was similar for uniconazole- and daminozide-treated plants for both cultivars.

Wilfret (1988) and Starman (1990) found that uniconazole is an effective growth regulator for potted chrysanthemum but that cultivar sensitivity varied. Plants of 'BGA and 'YF' used in this study were grown during different seasons (i.e., different environmental conditions); therefore, a direct comparison of cultivar sensitivity is precluded. Indirectly, unequal cultivar sensitivity to uniconazole compared to daminozide is suggested. Therefore, a range of spray concentrations and/or timing schedules, rather than an optimum application concentration, is implied.

\section{Literature Cited}

Barrett, J.E. and T.A. Nell. 1986. Evaluation of XE-1019 and paclobutrazol for height control of flowering annuals. Proc. Plant Growth Regulat. Soc. Amer. 13:62-64.

Barrett, J.E. and T.A. Nell. 1987. Efficacy and phytotoxicity of paclobutrazol and XE-1019 on vinca. Proc. Fla. State Hort. Soc. 100:382-383.

Davis, T.D., G.L. Steffens, and N. Sankhla. 1988 Triazole plant growth regulators. Hort. Rev. 10:63-105.
Himmelfarb, H. 1975. What do you do when the control group doesn't fit into the factorial design? Psychological Bul. 82:363-368.

Miller, M.R. and D.A. Bailey. 1989. Whole-plant response of Easter lilies to ancymidol and uniconazole. ASHS 1989 Annu. Mtg., Tulsa, Okla., Prog. \& Abstr. p. 77.

Pobudkiewicz, A.K. and K.L. Goldsberry. 1989. Response of dwarf carnation 'Snowmass' to growth retardant application. Colorado State Univ. Expt. Sta. Res. Bul. 468.

Starman, T.W. 1990. Whole-plant response of chrysanthemum to uniconazole foliar sprays or medium drenches. HortScience 25:935-937.

Stephenson, J.C. and R.L. Shumack. 1987. Sumagic shows promise as growth regulator for poinsettia production, Alabama Agr. Expt. Sta. Res. Bul. 5.

Tayama, H.K. and S.A. Carver. 1990. Zonal geranium growth and flowering responses to six growth regulators. HortScience 25:82-83.

Tayama H.K. and T.J. Roll (eds.). 1989. Tips on growing potted chrysanthemums. Ohio Coop. Ext. Bul. FP-767.

Wilfret, G.J. 1988. Effect of XE-1019 on height of containerized chrysanthemums. ASHS/CSHS 1988 Annu. Mtg., East Lansing, Mich., Prog. \& Abstr. HortScience 23(3):819[163]. 